\title{
In Memory of Nicola Scopinaro: a Great Friend and Mentor
}

\section{Luigi Angrisani $^{1}$}

Published online: 17 November 2020

(C) Springer Science+Business Media, LLC, part of Springer Nature 2020

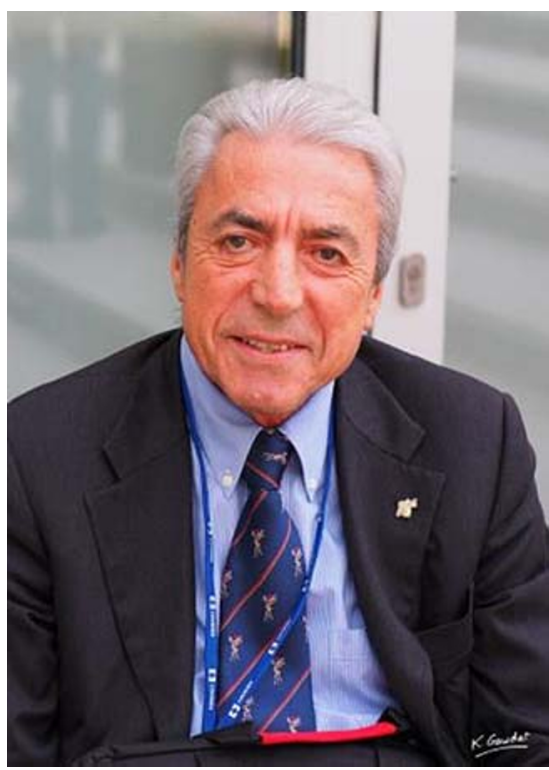

Nicola Scopinaro, MD, FACS (Hon)

1945-2020

I met Nicola Scopinaro in 1995 in Todi, a small and enchanting medieval town in Umbria, central Italy, during a hands-on-course on lap band. Many of us young Italian "laparoscopic surgeons" were there, eager to learn laparoscopic techniques and its application to obesity surgery. He was there as a witness of the national and international surgical academy, with profound classic knowledge of the discipline that he himself was trying to shape and establish.

Listening to his presentations, we were extremely impressed by his rigorous modern scientific method and detailed knowledge of whatever was under development worldwide in the field. While we were having a friendly talk (we did not know each other before), he introduced me to his partner Marina, a beautiful, elegant, blond woman who has been his affectionate

Luigi Angrisani

luigiangrisani@chirurgiaobesita.it

1 Public Health Department - School of Medicine, "Federico II" University of Naples, Naples, Italy companion till the end of his life. From that point on, we interacted more often, developing projects, sharing ideas, always pursuing quality in research, clinical application, and social life.

What was truly amazing about my relationship with Nicola was the fact that by the time I met him for the first time, he was only 50 and he could have already written a book or made a movie about his life. In fact he Nicola had created an original operation from his laboratory experience in dogs and human volunteers. This operation, which carries his name, was quickly adopted around the world.

As an invited speaker, Professor Scopinaro had traveled all over the world. He had survived two dreadful accidents, one when he was parachuting and another one few years later while he was driving his car. He used to drive a classic Porsche 911 and travel through Italy on his own airplane.

One of Nicola's greatest achievements was in 1995 in Stockholm. Nicola founded the International Federation for Surgery of Obesity (IFSO), the preeminent international bariatric surgery society that has united the world to address the epidemic of obesity and related metabolic disorders.

Another great achievement occurred when laparoscopic techniques in obesity surgery were new and not yet universally accepted. Although he was somewhat skeptical regarding the possibility of performing complex gastrointestinal operations with small incisions and laparoscopes, Nicola accepted my proposal to organize the First International Symposium of Laparoscopic Obesity Surgery with IFSO endorsement. It was held in Naples in March 1999. It was the beginning of a new era.

The meeting was attended by surgeons from 27 countries. They included the old guard pioneers of open bariatric surgery, such as Mason, MacLean, and many IFSO leaders, together with the young foxes who supported the laparoscopic approach. The following year, in May 2000, in his home city of Genoa, Italy, the IFSO World Congress was held. Nicola was the president of IFSO at the time, and the conference was another tremendous success. The opening 1-h lecture by Professor Scopinaro was his moral testament that we will never forget: "My Way."

By the time I joined the international scientific community and also socialized with him more frequently, I 
noticed that he intensively traveled all over the world, always teaching, debating, operating, writing, and preparing talks. Nicola fought for his ideas with incredible strength and enthusiasm. With the same style and enthusiasm, he appreciated the pleasures of life, especially drinking good wine with his IFSO friends. It is unbelievable, but for Nicola, this was the second round!

I keep trying to interpret the reactions of bariatric surgeons all over the world. I think that his presence was so important, even when he was not physically there. Now it is hard to accept the idea that he will not be with us anymore. I am sure that some of us, including me, have always thought that a man like him could never die. We have been very fortunate to have had this exceptional polyhedric personality with us in our beloved field of surgery. He will always be in our minds as a giant for his scientific research achievements and long-lasting contributions to the evolution of our discipline. We will also always cherish his joyful and affectionate friendship.

Goodbye Nicola, with all my heart.

$\sim$ Luigi Angrisani

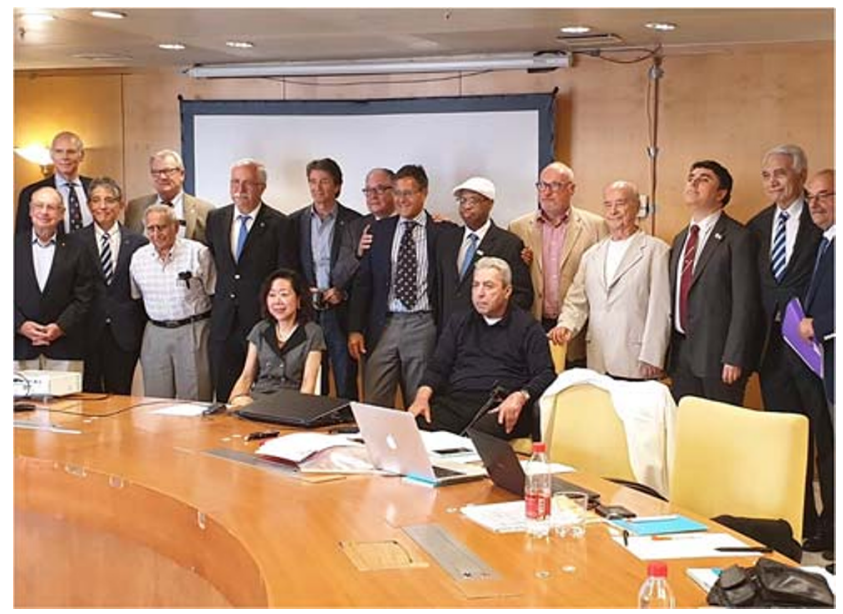

Please Note: Henry Buchwald, $\mathrm{MD}, \mathrm{PhD}$, will be authoring an article celebrating Prof. Scopinaro's life in a subsequent issue of Obesity Surgery. If you are interested in contributing an anecdote, reminiscence, or tribute to the article, please send your material to Dr. Buchwald at obsu.rodriguez@gmail.com.

For more information about Prof. Scopinaro's life, please read his brief biography, originally published in Obesity Surgery 14 April 2016: https:// link.springer.com/article/10.1007/s11695-016-2166-4.

Publisher's Note Springer Nature remains neutral with regard to jurisdictional claims in published maps and institutional affiliations. 